\title{
ELECTRICAL CONDUCTIVITY AND QUALITY OF DIFFERENT UMBEL ORDER CARROT SEEDS
}

\author{
Luana de Souza Marinke', Hugo Cesar Rodrigues Moreira Catão², Gabrielly Fernanda Francisco², \\ Ítala Menegon Castilho ${ }^{3}$, Letícia Rodrigues de Oliveira ${ }^{3}$, Talis Melo Claudino ${ }^{4}$
}

\begin{abstract}
Carrot seeds exhibit irregular vigor due to the wide blooming period of the crop. Results from germination tests are insufficient to evaluate the physiological potential. Thus, vigor tests are used in combination with germination tests. The objective of this work was to evaluate the quality of carrot seeds from different umbel order and the electrical conductivity under different temperatures and imbibing periods. Carrot seeds from cultivar Brasilia were used to perform the experiments. Content of water, the first and the final score of the germination test, index of germination rate, and length of roots and of the aerial portion were determined in the initial characterization. The electrical conductivity test was completed with replicates containing 50 seeds, in $25 \mathrm{~mL}$ deionized water at 20,25 and $30^{\circ} \mathrm{C}$. Evaluations were performed with 2, 4, 6, 8, 12 and 24 hours of imbibing period. The experiment was accomplished under a completely random statistical design. The quality of carrot seeds varied according to the umbel order. Seeds of secondary umbels showed better physiological quality. The electrical conductivity test is efficient to evaluate the vigor of carrot seeds with 8 hours of imbibing period at $25^{\circ} \mathrm{C}$.
\end{abstract}

Keywords: Daucus carota, imbibing period, temperature, vigor test.

\section{CONDUTIVIDADE ELÉTRICA E QUALIDADE DE SEMENTES DE DIFERENTES ORDENS DE UMBELA DE CENOURA}

\begin{abstract}
RESUMO - As sementes de cenoura possuem vigor desuniforme devido ao amplo periodo de florescimento. Os resultados do teste de germinação são insuficientes para a avaliação do potencial fisiológico. Assim, os testes de vigor são utilizados em conjunto com o teste de germinação. Portanto, objetivou-se avaliar a qualidade de sementes de cenoura de diferentes ordens de umbela e a condutividade elétrica em diferentes temperaturas e periodos de embebição. Para a realização dos experimentos foram utilizadas sementes de cenoura da cultivar Brasília. Na caracterização inicial determinou-se o teor de água, a primeira e a contagem final do teste de germinação, índice de velocidade de germinação, comprimentos da parte aérea e das raízes. Para o teste de condutividade elétrica utilizou repetições de 50 sementes, em $25 \mathrm{~mL}$ de água deionizada, a 20, 25 e $30^{\circ} \mathrm{C}$. As avaliações foram realizadas nos periodos de 2, 4, 6, 8, 12 e 24 horas. O delineamento foi inteiramente casualizado. A qualidade das sementes de cenoura variou de acordo com a ordem da umbela. As sementes das umbelas secundárias apresentaram melhor qualidade fisiológica. O teste de condutividade elétrica é eficiente na avaliação do vigor de sementes de cenoura com 8 horas de embebição a $25^{\circ} \mathrm{C}$.
\end{abstract}

Palavras chave: Daucus carota, periodo de embebição, temperatura, teste de vigor.

\footnotetext{
${ }^{1}$ Universidade Estadual de Londrina, Departamento de Agronomia, Londrina, PR, 86057-970, Brasil.

${ }^{2}$ Instituto de Ciências Agrárias, Universidade Federal de Uberlândia, Uberlândia, MG, 38410-337, Brasil.

${ }^{3}$ Centro Universitário das Faculdades Integradas de Ourinhos, Departamento de Agronomia, Ourinhos, SP, 19909-100, Brasil.

${ }^{4}$ Universidade Estadual Paulista (Unesp), Faculdade de Ciências Agronômicas, Botucatu, SP, 18610-034, Brasil.
} 


\section{INTRODUCTION}

Plants of carrot (Daucus carota L.) exhibit a wide blooming period, thus generating highly irregular vigor seeds, even when produced under uniform soil and climatic conditions and derived from the same population (Lima \& Athanázio, 2009).

The employment of certified quality seeds constitutes an important factor in the establishment of crops, allowing higher yields (Catão et al., 2013). According to Bittencourt et al. (2012), it is of vital importance that physiological potential of seeds has been obtained through tests which may supply reliable information, to take decisions during production and commercialization of those seeds.

Results provided by germination test are considered insufficient to evaluate the physiological potential of seeds in field conditions (Ohlson et al., 2010), once this is performed under optimal water, aeration and temperature conditions (Brasil, 2009). Within this context, the use of fast, reliable and easy methods is fundamental to evaluate the physiological potential of seeds.

Vigor tests are used in conjunction to germination tests, to support decisions, increase agility and efficiency of quality control (Bittencourt et al.; 2012). Amongst the fastest tests studied, the electrical conductivity is related with the initial events of the deterioration sequence in seeds (Bewley \& Black, 1994; Ortiz, et al., 2018). The results are obtained through indirect evaluation of the structural degree of the cell membranes by means of determining the quantity of leached ions in the imbibing solution (Vieira \& Krzyzanowski, 1999; Marcos Filho, 2015).

Electrical conductivity has been widely used to evaluate seed's vigor with consistent results, especially for large crop seeds. However, some researchers are attempting to standardize this test to evaluate vegetable seeds, as in studies completed in pepper (Vidigal et al., 2008) and onions (Rosa et al., 2015).

Diverse factors may influence the results of the electrical conductivity test, among those the plant genotype, loss of structure in cell membranes, size and number of seeds in the sample, presence of pathogens, temperature and imbibing period as the most significant (Wain-Tassi et al., 2012). These factors are the focus of research aiming more consistent results, especially when regarding the temperature and the imbibing period which are considered factors of extreme importance (Avelino et al., 2018). Besides, carrot seeds may show uneven vigor status and the availability of information concerning the techniques to perform such vigor evaluation are also scarce. The objective of this work was to evaluate the quality of carrot seeds from different umbel order and electrical conductivity under different temperatures and imbibing periods.

\section{MATERIAL AND METHODS}

The experiment was completed in the field and in the Seed Laboratory from the Integrated Faculties from Ourinhos (FIO), Ourinhos-SP. The climatic conditions were typical from sub-tropical regions in Brazil, classified as $\mathrm{Cfa}$ according Köppen. The mean annual temperature and rainfall were of $21.2^{\circ} \mathrm{C}$ and $1339 \mathrm{~mm}$, respectively.

Carrot seeds from cultivar Brasília were produced in seedbeds with spacing of $20 \mathrm{~cm}$ between rows and $5 \mathrm{~cm}$ between plants. Cultural treatments were accomplished according to the crop needs, with thinning being executed 25 days after sowing. Seeds were harvested 120 days after blooming, collecting seeds from the primary, secondary and tertiary umbels separately.

The initial characterization of the physiological quality of seeds from different umbel order was performed through the following tests:

Water content: accomplished through the method of an oven at $105 \pm 3^{\circ} \mathrm{C}$, using two sub-samples of $50 \mathrm{~g}$ of seeds each, according Brasil (2009).

Germination test and first counting: seeds were sowed over two blotting paper foils, previously dampened with distilled water at a proportion of 2.5 times the weight of the dry substrate, in gerbox plastic boxes. Boxes with seeds remained in B.O.D. chambers at $20^{\circ} \mathrm{C}$ under a 12 hours photoperiod. The evaluation constituted of two counts of normal plants, seven and fourteen days after the test started (Brasil, 2009). Four replicates with 50 seeds were analyzed and the results were expressed as percentage of normal plants.

Index of germination rate: this evaluation was performed simultaneously with the germination test, computing every day, the number of germinated seeds. Seeds were considered germinated when showing protrusion of the radicle. The index was calculated according to the formula proposed by Maguire (1962).

Length of the roots and the aerial portion: the analysis was achieved from seeds sowed on blotting paper as described previously. Four replicates with 10 seeds of each umbel order were used, arranged in alternated form. After 14 days the length of the roots and the aerial portion 
were measured with the aid of a graduated ruler, and the results expressed in centimeters.

The electrical conductivity test was performed by the bulk method, using four replicates with 50 seeds for each umbel order. Seeds were weighed in analytical balance (precision of $0.001 \mathrm{~g}$ ) and conditioned in plastic cups with $200 \mathrm{~mL}$ capacity, containing $25 \mathrm{~mL}$ of deionized water. Then, cups remained in B.O.D. chambers at temperatures of 20,25 and $30^{\circ} \mathrm{C}$, with evaluations were acomplished in six imbibing periods with $2,4,6,8,12$ and 24 hours.

Electrical conductivity measurements were accessed with a Tecnal TEC-4MP digital conductivity meter, registering the results at the end of the evaluation. The equipment was calibrated with readings of up to 2000 $\mu \mathrm{S} . \mathrm{cm}^{-1}$, variation of $2.02 \%$ and standard solution of $146.9 \mu{\mathrm{S} . \mathrm{cm}^{-1}}^{1}$ at $25^{\circ} \mathrm{C}$. The experimental design used was completely random with four replicates in a $3 \times 6$ factorial scheme, with 3 umbel orders and 6 imbibing periods $(2,4$, $6,8,12$ and 24 hours), isolated at temperatures of 20,25 and $30^{\circ} \mathrm{C}$. Data was analyzed statistically using the $\mathrm{F}$ test and variance analysis at 5\% probability, the Scott- Knott test at $5 \%$ probability was used when significant effects were detected, with the aid of the software SISVAR 5.0 (Ferreira, 2011).

\section{RESULTS AND DISCUSSION}

According to the results showed in Table 1, it was possible to observe significant differences in the physiological quality of carrot seeds. Data regarding the water content were similar among seeds from different umbel order. Water content in seeds during the test was of $7.3 \%, 6.7 \%$ and $7.4 \%$ in seeds of the primary, secondary and tertiary umbel, respectively. Guedes et al. (2011) stresses that differences from 1 to $2 \%$ in water content between samples are not significant, allowing the tests to proceed, that is to say, this percentage is considered within the range which does not influence the results of the electrical conductivity test.

Table 1 - Initial characterization of carrot seeds from different umbel order by the tests of first germination count (PCG), germination $(\mathrm{G} \%)$, length of the aerial portion $(\mathrm{CPA})$ and root length $(\mathrm{CR})$

\begin{tabular}{lcccccc}
\hline \multirow{2}{*}{ Umbel } & \multicolumn{5}{c}{ Initial characterization } \\
\cline { 2 - 7 } & Water Content $(\%)$ & PCG $(\%)$ & G $(\%)$ & IVG & CPA $(\mathrm{cm})$ & CR $(\mathrm{cm})$ \\
\hline Primary & 7.3 & $47 \mathrm{~A}$ & $73 \mathrm{~A}$ & $4.98 \mathrm{~A}$ & $5.12 \mathrm{~B}$ & $4.05 \mathrm{~A}$ \\
Secondary & 6.7 & $48 \mathrm{~A}$ & $69 \mathrm{~A}$ & $5.25 \mathrm{~A}$ & $4.55 \mathrm{~B}$ & $3.69 \mathrm{~A}$ \\
Tertiary & 7.4 & $40 \mathrm{~B}$ & $55 \mathrm{~B}$ & $2.09 \mathrm{~B}$ & $6.54 \mathrm{~A}$ & $3.45 \mathrm{~A}$ \\
\hline CV $(\%)$ & & 6.10 & 10.50 & & 18.97 & 20.04 \\
\hline
\end{tabular}

* Means followed by the same capital letter within the column are not statistically different by the test of Scott Knott at $5 \%$ probability.

Concerning the first germination count, a lower percentage of normal plants was observed in seeds from the tertiary umbel. According Marcos Filho (2015), the first count is extremely important to evaluate seed vigor, the higher the germination percentage of a determined seed lot, the higher its vigor. The lowest germination percentage was also observed in seeds from the tertiary umbel. It must be emphasized that germination test was performed under ideal environmental conditions of luminosity, temperature and relative humidity. Therefore, such test not always will reveal differences in performance between seed lots (Mattioni et al., 2015).

The highest viability was observed in seeds from first and secondary umbel (Table 1). According to the index of germination rate results, seeds from tertiary umbels were less vigorous than seeds form primary and secondary umbels. Similar results were observed by Rodo (2001), demonstrating there was no decrease in seed germination as umbel order increased. However, Santos et al. (2010) observed that seeds from the primary umbel showed a reduction in germination.

Regarding the length of the aerial portion, seeds from the tertiary umbel differed statistically form the rest. Such phenomenon was not observed concerning root length, which did not differentiate statistically. According Santos et al. (2010), differences in the aerial portion and root length constitute a signal of the existence of physiological quality differences among seeds. Thus, in the present study, tests performed to initially characterize the physiological quality were efficient to differentiate seeds from each umbel order. Consequently, seeds from the tertiary umbel showed lesser 
vigor, although no differences were verified for seeds from the primary and secondary umbels.

When analyzing Table 2 it is possible to observe significant differences between the umbel orders and the imbibing periods of the electrical conductivity test, as well as for the interaction of the evaluated factors $(\mathrm{P}<0.05)$. The deterioration process causes degenerative changes of the membrane system, reducing its integrity and/or selectivity, producing loos of control in water and solute exchanges between the cells and the exterior environment, determining the reduction of seed viability (Binotti et al., 2008). Thus, the electrical conductivity test used to evaluate seed vigor in function of the leachate quantities, varied according to the methods used in the present study (Table 2).

Table 2 - Electrical conductivity $\left(\mu \mathrm{S} \mathrm{cm}^{-1} \mathrm{~g}^{-1}\right)$ in carrot seeds cv. Brasília, at temperatures of 20,25 and $30^{\circ} \mathrm{C}$ as a function of umbel order and imbibing period

\begin{tabular}{|c|c|c|c|c|c|c|}
\hline \multirow{2}{*}{ Umbel } & \multicolumn{6}{|c|}{ Imbibing period $(\mathrm{h})$} \\
\hline & 2 & 4 & 6 & 8 & 12 & 24 \\
\hline \multicolumn{7}{|c|}{$20^{\circ} \mathrm{C}$} \\
\hline Primary & $294.39 \mathrm{Ba}$ & $399.96 \mathrm{Bb}$ & $472.25 \mathrm{Bb}$ & $501.39 \mathrm{Bb}$ & $660.49 \mathrm{Bc}$ & $890.40 \mathrm{Bd}$ \\
\hline Secondary & $76.56 \mathrm{Aa}$ & $119.79 \mathrm{Aa}$ & $170.97 \mathrm{Aa}$ & 172.97 Aa & $242.83 \mathrm{Ab}$ & $335.78 \mathrm{Ab}$ \\
\hline Tertiary & $5.84 \mathrm{Aa}$ & $57.79 \mathrm{Aa}$ & $110.16 \mathrm{Aa}$ & $110.16 \mathrm{Aa}$ & $189.23 \mathrm{Ab}$ & $276.04 \mathrm{Ab}$ \\
\hline \multicolumn{7}{|c|}{$\mathrm{CV}(\%)=38.23$} \\
\hline \multicolumn{7}{|c|}{$25^{\circ} \mathrm{C}$} \\
\hline Primary & $284.16 \mathrm{Ba}$ & $460.42 \mathrm{Ba}$ & $634.37 \mathrm{Bb}$ & $769.55 \mathrm{Cb}$ & $949.86 \mathrm{Cc}$ & $1337.00 \mathrm{Cd}$ \\
\hline Secondary & $32.32 \mathrm{Aa}$ & $146.51 \mathrm{Aa}$ & $266.52 \mathrm{Ab}$ & $377.32 \mathrm{Ab}$ & $445.49 \mathrm{Ac}$ & $646.74 \mathrm{Ac}$ \\
\hline Tertiary & $80.03 \mathrm{Aa}$ & $243.66 \mathrm{Aa}$ & $266.52 \mathrm{Ab}$ & $555.74 \mathrm{Bb}$ & $786.56 \mathrm{Bc}$ & $1200.12 \mathrm{Bd}$ \\
\hline \multicolumn{7}{|c|}{$\mathrm{CV}(\%)=26.76$} \\
\hline \multicolumn{7}{|c|}{$30^{\circ} \mathrm{C}$} \\
\hline Primary & $361.22 \mathrm{Ba}$ & $516.03 \mathrm{Ba}$ & $659.58 \mathrm{Ba}$ & $796.93 \mathrm{Bb}$ & $1014.94 \mathrm{Bb}$ & $2077.20 \mathrm{Cc}$ \\
\hline Secondary & $363.20 \mathrm{Ba}$ & $480.83 \mathrm{Ba}$ & $611.43 \mathrm{Ba}$ & $733.53 \mathrm{Bb}$ & $897.07 \mathrm{Bb}$ & $1814.56 \mathrm{Bc}$ \\
\hline Tertiary & $83.62 \mathrm{Aa}$ & $235.62 \mathrm{Aa}$ & $351.80 \mathrm{Ab}$ & $452.14 \mathrm{Ab}$ & $582.41 \mathrm{Ab}$ & $1334.66 \mathrm{Ac}$ \\
\hline $\mathrm{CV}(\%)=2$ & & & & & & \\
\hline
\end{tabular}

* Means followed by the same capital letter within the column and lowercase letter in the row are not statistically different by the Scott Knott test at $5 \%$ probability.

When the electrical conductivity test was performed at a temperature of $20^{\circ} \mathrm{C}$, it was possible to stratify seeds from three different umbel orders in only two vigor categories. Seeds from primary umbel showed a higher deterioration level and higher leachate quantities. Seeds from superior umbels showed a bigger size, thus may have greater mechanical damages and higher deterioration than lower umbel seeds (Rodo et al., 2001). Rodo et al. (2001) also observed that seeds from primary umbels have and early maturation in the field, losing quality over time, until the other umbels are mature, and the harvest is done. This fact explains the higher deterioration level of such seeds.
A slight difference in the quality of carrot seeds was observed at a temperature of $20^{\circ} \mathrm{C}$ in the present work. However, Domiciano et al. (2015) observed that only at a temperature of $20^{\circ} \mathrm{C}$ a difference was observed in carrot seed lots. Seeds from secondary and tertiary umbels had no statistical difference in any of the imbibing periods tested. Thus, these seeds hold a better quality and vigor according to the tests applied in the present work, corroborating results obtained by Torres et al. (2015).

The electrical conductivity test is generally applied at $25^{\circ} \mathrm{C}$ (Marcos Filho, 2015). Such temperature is considered standard when applying this test, allowing to differentiate seed lots in vigor levels. As observed in Table 
2 , at this temperature was also possible to stratify the seeds. The constitution of three vigor classes was verified in the imbibing period of 8 hours, classes which remained the same in the following periods. Seeds from primary umbel showed a higher level of deterioration, followed by seeds from tertiary and secondary umbels. Therefore, seeds from secondary umbels are more vigorous.

Domiciano et al. (2015) observed that at a temperature of $25^{\circ} \mathrm{C}$ lots of carrot seeds did not differ statistically. Although Rosa et al. (2015) concluded that at a temperature of $25^{\circ} \mathrm{C}$ lots of onion seeds differed, once they showed higher quantities of leachates in water, this may allow inferring that such standard temperature of $25^{\circ} \mathrm{C}$ may be efficient or not, depending on the crop to be evaluated.

At a temperature of $30^{\circ} \mathrm{C}$, seeds from primary and secondary umbels were statistically equal until the imbibing period of 24 hours. Such imbibition temperature propitiated an equality of means, reducing the difference between seed vigor levels. Carvalho et al. (2009) emphasized that high temperatures and long exposition periods promote the concentration and stabilization of mean values for leachates of the electrical conductivity test.

At a temperature of $30^{\circ} \mathrm{C}$ a high quantity of electrolytes in the imbibing water was also evidenced. According to Bewley \& Black (1994), high temperatures may promote an increase in leachates and this may be due to the loss of structure of the cell membrane system, which is correlated with membrane integrity, thus inhibiting the re-organization of membranes and therefore increasing the leachates in the seeds' imbibing solution.

Imbibing periods of 12 and 24 hours, at a temperature of $30^{\circ} \mathrm{C}$, were inefficient to evaluate seed vigor. In these periods a high quantity of leachates in the water was observed, independently form umbel order, turning the use of conductivity tests unfeasible. According to Marcos Filho (2015), temperature has a great importance because it is related with the exposition period of seeds, therefore, the higher the temperature, the higher the electrolyte leachates will be.

At $30^{\circ} \mathrm{C}$ the electrolyte leaching was lower in seeds from tertiary umbels, when compared with other seeds. This may have occurred due to the seeds being smaller. Corroborating with the results observed in the present work, Domiciano et al. (2015) verified that a temperature of $30^{\circ} \mathrm{C}$ it was not possible to identify differences in vigor of carrot seeds. On the other hand, Dutra \& Vieira (2006) verified that at $30^{\circ} \mathrm{C}$ temperature it was possible to differentiate the quality of summer squash seed lots. Before that information, we observed temperatures of $30^{\circ} \mathrm{C}$ allows to differentiate seed lots, however depending on the crop seed evaluated.

As the imbibing period increased there was an escalation in the quantities of released electrolytes by the seeds with a tendency to a stabilization and, therefore, with the possibility of an anticipated evaluation of seed vigor (Table 2). Electrical conductivity was also sustained from 8 until 24 hours of imbibing period while evaluating seeds of Vigna unguiculata by Moura et al. (2017).

Due to the great number of samples demanding evaluations in the laboratories it is primordial to obtain promptly results, without jeopardizing consistence and reliability. Thus, the increment of leachate electrolytes during the imbibing period of 8 hours at $25^{\circ} \mathrm{C}$ allowed a safe evaluation of carrot seed quality. The reduction of imbibing period is of extreme importance for the industry of seeds, to rapidly determine the quality of seeds.

The imbibing period of 24 hours is established for readings of electrical conductivity (Vieira \& Krzyzanowski, 1999). However, Dutra and Vieira (2006) determined also a period of 8 hours as being sufficient to evaluate the vigor of summer squash seeds, once the contents of leachates conserved a tendency. Vidigal et al. (2008) while evaluating the quality of pepper seeds verified efficient results for vigor analysis after an hour of imbibing period. The reduction of the imbibing period for the electrical conductivity test was also observed during the evaluation of seed vigor in beans (Silva et al., 2014).

Xavier et al. (2017) determined a period of 4 hours as sufficient to separate lots with 50 seeds of Blackeyed pea. Using 50 seeds of coriander, Torres et al. (2015) verified the evaluation of vigor in the seed lots was efficient as soon as 2 hours of imbibing.

Consequently, the present work confirmed that electrical conductivity test was efficient to evaluate the physiological potential of seeds with different umbel order, allowing to differentiate them with extreme efficiency. This reinforces the fact that methodologies used in the imbibing periods were coherent to evaluate the vigor of carrot seeds.

\section{CONCLUSIONS}

Quality of carrot seeds varied according to the umbel order. Seeds from secondary umbels showed better physiological quality. The electrical conductivity test is efficient to evaluate the vigor of carrot seeds with 8 hours of imbibing period at $25^{\circ} \mathrm{C}$. 


\section{LITERATURE CITED}

AVELINO, M. C. S.; FELIX, F. C.; SILVA, K. R. G.; ARAÚJO, F. S.; PACHECO, M. V. Testes bioquímicos de integridade de membranas na avaliação do vigor de sementes de Mimosa caesalpiniifolia Benth. Revista de Ciências Agrárias, Lisboa, v.41, n.1, p.100-108, 2018.

BEWLEY, J. D.; BLACK, M. Seeds: physiology of development and germination. 2. ed. New York: Plenum Press, 1994. 455p.

BINOTTI, F. F. S.; HAGA, K. I.; CARDOSO, E. D.; ALVES, C. Z.; SÁ, M. E.; ARF, O. Efeito do período de envelhecimento acelerado no teste de condutividade elétrica e na qualidade fisiológica de sementes de feijão. Acta Scientiarum Agronomy, Maringá, v.30, n.2, p.247254, 2008.

BITTENCOURT, S. R. M.; GRZYBOWSKI, C. R. S.; PANOBIANCO, M.; VIEIRA, R. D. Metodologia alternativa para condução do teste de envelhecimento acelerado em sementes de milho. Ciência Rural, Santa Maria, v.42, n.8, p.1360-1365, 2012.

BRASIL. Ministério da Agricultura e Reforma Agrária. Regras para análise de sementes. Brasília: SNDA/DNDV/ CLAV, 2009. 395p.

CARVALHO, L. F.; SEDIYAMA, C. S.; REIS, M. S.; DIAS, D. C. F. S.; MOREIRA, M. A. Influência da temperatura de embebição da semente de soja no teste de condutividade elétrica para avaliação da qualidade fisiológica. Revista Brasileira de Sementes, Londrina, v.31, n.1, p.009-017, 2009.

CATÃO, H. C. R. M.; MAGALHÃES, H. M.; SALES, N. L. P.; BRANDÃO JUNIOR, D. S.; ROCHA, F.S. Incidência e viabilidade de sementes crioulas de milho naturalmente infestadas com fungos em pré e pós-armazenamento. Ciência Rural, Santa Maria, v.43, n.5, p.764-770, 2013.

DOMICIANO, C. A.; TEIXEIRA, S. O.; CARVALHO, M. A. C.; YAMASHITA, O. M.; DALLACORT, R. Teste de condutividade elétrica para avaliação da qualidade fisiológica de sementes de cenoura. Enciclopédia Biosfera, Goiânia, v.11, n.21, 2015.

DUTRA, A. S.; VIEIRA, R. D. Teste de condutividade elétrica para a avaliação do vigor de sementes de abobrinha. Revista Brasileira de Sementes, Londrina, v.28, n.2, p.117122, 2006.

FERREIRA, D. F. Sisvar: a computer statistical analysis system. Ciência e Agrotecnologia, Lavras, v.35, n.6, p.10391042, 2011.
GUEDES, R. S.; ALVES, E. U.; OLIVEIRA, L. S. B.; ANDRADE, L. A.; GONÇALVES, E. P.; MELO, P. A. R. F. Envelhecimento acelerado na avaliação da qualidade fisiológica de sementes de Dalbergia nigra (Vell.) Fr. All. Semina: Ciências Agrárias, Londrina, v.32, n.2, p.443-450, 2011.

LIMA, C. B.; ATHANÁZIO, J. C. Testes de vigor para sementes de cenoura. Scientia Agraria, Curitiba, v.10, n.6, p.455-461, 2009.

MAGUIRE, J. D. Speed of germination-aid in selection and evaluation for seedling emergence and vigor. Crop Science, Madison, v.2, p.176-177, 1962.

MARCOS FILHO, J. Fisiologia de sementes de plantas cultivadas. Piracicaba: FEALQ, 2015. 495p.

MATTIONI, N. M.; MERTZ, L. M.; BARBIERI, A. P. P.; HAESBAERT, F. M.; GIORDANI, W.; LOPES, S. J. Individual electrical conductivity test for the assessment of soybean seed germination. Semina: Ciências Agrárias, Londrina, v.36, n.1, p.31-38, 2015.

MOURA, M. C. F.; LIMA, L. K. S.; SANTOS, C. C.; DUTRA, A. S. Teste da condutividade elétrica na avaliação fisiológica em sementes de Vigna unguiculata. Revista de Ciências Agrárias, Lisboa, v.40, n.4, 2017.

OHLSON, O. C.; KRZYZANOWSKI, F. C.; CAIEIRO, J. T.; PANOBIANCO, M. Teste de envelhecimento acelerado em sementes de trigo. Revista Brasileira de Sementes, Londrina, v.32, n.4, p.118-124, 2010.

ORTIZ, T. A.; GOMES, G. R.; VENGRUS, N. A. S.; ANSCHAU, R.; TAKAHASHI, L. S. A. Electrical conductivity test for evaluating physiological quality in snap bean (Phaseolus vulgaris L.) seeds. Australian Journal of Crop Science, v.12, n.10, p.1561-1565, 2018.

RODO, A. B.; PERLEBERG, C. S.; TORRES, S. B.; GENTIL, D. F. O.; TESSARIOLI NETO, J. Qualidade fisiológica e tamanho de sementes de cenoura. Scientia Agricola, Piracicaba, v.58, n.1, p.201-204, 2001.

ROSA, R. C. T.; MOURA, J. F.; GONÇALVES, A. P. S.; GURGEL, L. M. S.; ASSIS, T. C.; ANDRADE, D. E. G. T.; SANTOS, A. M. G. Teste de condutividade elétrica para avaliação da qualidade fisiológica de sementes de cebola. Anais da Academia Pernambucana de Ciência Agronômica, Recife, v.11, n.12, p.242-255, 2015.

SANTOS, V. J.; GARCIA, D. C.; LOPES, S. J.; EICHELBERGER, L. Qualidade fisiológica de sementes de cenoura classificadas por tamanho. Ciência Rural, Santa Maria, v.40, n.9, p.1903-1908, 2010. 
SILVA, J. E. N.; MELHORANÇA FILHO, A. L.; SILVA, R. G. P. O. Teste de condutividade elétrica para sementes de feijão manteiguinha. Ensaios e Ciências: Ciências Biológicas, Agrárias e da Saúde, v.17, n.6, p.37-46, 2014.

TORRES, S. B.; PAIVA, E. P.; ALMEIDA, J. P. N.; BENEDITO, C. P.; CARVALHO, S. M. C. Teste de condutividade elétrica na avaliação da qualidade fisiológica de sementes de coentro. Revista Ciência Agronômica, Fortaleza, v.46, n.3, p. 622-629, 2015.

VIDIGAL, D. S. LIMA, J. S.; BHERING, M. C.; DIAS, D. C. F. S. Teste de condutividade elétrica para sementes de pimenta. Revista Brasileira de Sementes, Londrina, v. 30, n. 1, p. $168-174,2008$.

VIEIRA, R. D.; KRZYZANOWSKI, F. C. Teste de condutividade elétrica. In: KRZYZANOWSKI, F. C.;
VIEIRA, R. D.; FRANÇA NETO, J. B. (Ed.). Vigor de sementes: conceitos e testes. Londrina: ABRATES, 1999. cap.3, p.1-24.

WAIN-TASSI, A. L.; SANTOS, J. F.; PANIZZI, R. C.; VIEIRA, R. D. Seed-borne pathogens and electrical conductivity of soybean seeds. Scientia Agricola, v.69, n.1, p.19-25, 2012.

XAVIER, F. M.; EBERHARDT, P. E. R..; ALMEIDA, A. S.; MARTINS, A. B. N.; CARVALHO, I. L.; TUNES, L. V. M. Teste de condutividade elétrica em sementes de feijão miúdo (Vigna unguiculata). Revista Verde de Agroecologia e Desenvolvimento Sustentável, Pombal, v.12, n.2, p.204209, 2017

Recebido para publicação em 28/02/2019 e aprovado em 01/12/2019. 